\title{
Effects of price discount on consumers' perceptions of savings, quality, and value for apparel products: mediating effect of price discount affect
}

\author{
Jung Eun Lee* and Jessie H. Chen-Yu
}

${ }^{*}$ Correspondence:

eljung@vt.edu

Department of Apparel,

Housing, and Resource

Management, Virginia

Tech, 295 W. Campus Drive,

Blacksburg, VA 24061, USA

\begin{abstract}
Extending the price-quality-value model (Monroe and Krishnan in The perception of merchandise and store quality 209-232, 1985) and means-end model (Zeithaml in J Mark 52:2-22, 1988), we developed a conceptual model to investigate the mediating role of price discount affect (feeling aroused by price discounts) in the relationship between price discounts and consumers' perceptions (perceived savings, quality, and value) and in the relationship between perceived value and purchase intentions in the context of online apparel products. A between-subject experimental design with four levels of price discounts (10,30,50, and 70\%) was used. Jeans were selected as the product stimulus. Web pages were developed to create a fictional online store and to collect data. A total of 209 usable responses were collected by a research firm in the United States, and structural equation modeling was performed to analyze the data. The results showed that price discount affect played an important mediating role in the relationship between price discounts and consumers' perceptions. When the direct effect of price discounts on perceived quality was examined, consumers perceived the apparel product with higher discounts as lower quality (i.e., a negative direct relationship). However, when price discount affect served as a mediator, the feelings created by a price discount led to a positive perception of product quality (i.e., a positive indirect relationship). By considering the influence of price discount affect, our model provides a better understanding of the effect of price discounts on consumers' perceptions of apparel products.
\end{abstract}

Keywords: Apparel, Price discount, Quality, Affect

\section{Introduction}

A price discount is a very prevalent marketing strategy to attract consumers by providing an extra value or incentive, which encourages consumers to purchase the promoted products immediately (Yin and Huang 2014). In marketing research, theoretical models have been developed to investigate the relationship between price and customers' perceptions of products, and two well-known models in the pricing literature are the pricequality-value model (Monroe and Krishnan 1985) and the means-end model (Zeithaml 1988). According to these models, price increases both perceived quality and perceived

(c) The Author(s) 2018. This article is distributed under the terms of the Creative Commons Attribution 4.0 International License (http://creativecommons.org/licenses/by/4.0/), which permits unrestricted use, distribution, and reproduction in any medium, provided you give appropriate credit to the original author(s) and the source, provide a link to the Creative Commons license, and indicate if changes were made. 
sacrifice (the sacrifice of paying more), and the trade-off between perceived quality and perceived sacrifice affects perceived value. When the price is high, consumers perceive that the quality of the product is high. With respect to price discounts, according to the price-quality-value model (Monroe and Krishnan 1985) and means-end model (Zeithaml 1988), consumers should perceive that more highly discounted products are of lower quality. However, researchers have found inconsistent results in the effects of price discounts on perceived product or service quality. Huang et al. (2014) and Rungtrakulchai (2013) found a positive relationship - a high price discount led to a perception of high product quality, Garretson and Clow (1999) found a negative relationship-a high price discount led to a perception of low quality, and Grewal et al. (1998a) found no relationship between price discounts and product quality. A possible reason for these inconsistent results is that the price-quality-value model and means-end model consider only the momentary effect of price, but price discounts have an affective effect that can create positive feelings. Chandon et al. (2000) identified the hedonic benefits of price promotions, including the value expression (self-perception of being smart or good shoppers), exploration (stimulation to explore a variety of new products due to the price promotion), and entertainment benefits (fun to use the price promotion).

The affective feeling, especially for apparel products, may have an important influence on consumers' perceptions of the product and the shopping experience (Clore et al. 2001). Chandon et al. (2000) found that price promotions were more effective when the benefits of the promotions were congruent with the type of products (i.e., hedonic vs. utilitarian products). When they purchase hedonic products, consumers prefer price promotions that come with the hedonic benefits to price promotions that come with the utilitarian benefits. In other words, the affective effect of promotion is particularly important for hedonic products. Unlike many other product categories, apparel products have a high hedonic value (Kim and Forsythe 2007; Kim and Hong 2011), which refers to the sense of pleasure associated with the product (Kaul 2007). In addition to the hedonic value of the product itself, consumers may also perceive a high hedonic shopping value associated with the price discount that they received when they shop for apparel (Jin et al. 2003). The affect created by price discounts (hereafter product discount affect) may play an important role in consumers' perceptions of apparel quality and value.

Although price promotion is especially popular in the apparel industry because of a short product life cycle, the study of price discount in apparel research remains a largely unexplored area, and no study to date has used pricing models to examine the affective influences of price discounts. To fill this void, this study investigated (a) the direct effects of price discount on consumers' perceptions of savings, quality, and price discount affect, (b) the direct effects of price discount affect on consumers' perceptions of savings, quality, and value, (c) the mediating role of price discount affect in the relationships between price discounts and consumers' perceptions of savings, quality, and value, (d) the direct effects of perceived savings on perceived value and of perceived quality on perceived value, and (e) the direct effect of perceived value on purchase intentions, particularly in online apparel shopping. 


\section{Literature review and hypothesis development \\ Price-quality-value model and means-end model}

The price-quality-value model proposed by Monroe and Krishnan (1985) and the means-end model proposed by Zeithaml (1988) have been widely used to investigate the relationship between price and customers' perceptions of products. The price-quality-value model describes the relationships between price, perceived quality, sacrifice, value, and willingness to buy. In the model, price is one of the external characteristics of a product that customers perceive as a stimulus. Perceived sacrifice is a measure of customers' perceptions about paying a price. Monroe and Krishnan (1985) proposed that consumers perceive price differently; some may perceive the objective price as high, while others may perceive it as low. Consumers' perceptions of product quality and monetary sacrifice are derived from consumers' perceptions of price. Consumers infer that a higher price signals a higher quality, but at the same time, the higher price indicates a greater monetary sacrifice in purchasing the product. Consequently, the trade-off between perceived quality (i.e., gain) and perceived sacrifice (i.e., loss) results in perceived value. Finally, customers base their purchase decisions on perceived value, and their willingness to buy increases as their perception of value increases.

Consistent with the price-quality-value model (Monroe and Krishnan 1985), the means-end chain model proposed by Zeithaml (1988) also describes the relationships between price, perceived quality, and perceived value. Originally proposed by Gutman (1982), a means-end chain is defined as one consisting of an interconnected set of cognitive elements that allows people to select objects or activities that enable these people to achieve their desired goals. This approach can help marketers understand the cognitive structure of product information that consumers retain in their memory at several levels of abstraction. Peter and Olson (1987) describe that a means-end chain is a conceptual structure linking product attributes to functional and psychosocial consequences, and then to personal perception of value. Zeithaml (1988) proposed a means-end model for consumers' perceptions of price, quality, and value, in which price is considered as an extrinsic cue of product attribute and price promotion can be a cue that signals quality change. This model supports that price promotion (an extrinsic cue of product attribute) may influence consumers' perception of product quality (perceptions of functional and psychosocial consequences) and consumers' perception of product quality is linked to consumers' perception of value. The means-end model shows that price influences perceived monetary price; perceived monetary price influences perceived sacrifice and perceived quality. Then perceived sacrifice and perceived quality influence perceived value, which in turn influences purchase intentions.

Researchers have applied the price-quality-value model (Monroe and Krishnan 1985) and the means-end chain model (Zeithaml 1988) to explain the effect of price on customers' perceptions and confirmed the relationships proposed in these models (Dodds et al. 1991; Palma et al. 2016; Rao and Monroe 1989; Suri and Monroe 2003). These studies have consistently shown that there is a positive effect of price on consumers' perceptions of quality. When the price is high, consumers perceive high product quality. 


\section{Effects of price discounts}

Previous studies in marketing have shown that price discounts have both positive and negative effects on customers' evaluations and purchasing behavior (Darke and Dahl 2003; Dorzdenko and Jensen 2005; Kocas and Bohlmann 2008). Raghubir et al. (2004) identified three routes of promotional effects: (a) economic, (b) informational, and (c) affective. They argued that the final effect of a price promotion on purchasing decision is a combination of positive and negative economic, informational, and affective influences.

\section{Economic effects of price discounts}

Economic effects of price discounts are created by a monetary gain or non-monetary (e.g., time and effort) gain or loss from a price promotion provided to customers (Raghubir et al. 2004). A positive monetary effect of price promotion can be produced by the face value of a coupon or the amount of a rebate. An example of a positive non-monetary effect is that price promotion can help customers simplify the decision process and reduce the transaction time or effort. However, there are potential negative economic effects of price promotions. Customers may spend more time finding the best deal or delay their purchase to wait for a promotional offer.

According to the economic effects of price discounts, a price discount provides a monetary gain, an incentive to encourage consumers to purchase the product. Consumers perceive a higher level of savings for a product when a higher price discount is provided, and this relationship was confirmed by many previous studies. The perceived savings concept has been used as the most common variable to measure the response to a price promotion, according to Krishna et al. (2002) meta-analysis. For example, perceived savings have been used as significant responses to comparison cues of a price promotion (i.e., the difference between an external reference price and the actual price; Berkowitz and Walton 1980), price promotion messages (e.g., percentage terms vs. dollar terms; Chen et al. 1998), and tensile price claims (e.g., save up to 50\%; Biswas and Burton 1993; Lee and Stoel 2016). In other words, perceived savings have been shown to be a useful measure of customers' perceptions of price promotions.

This proposition of a positive relationship between price discounts and perceived savings is consistent with the price-quality-value model and means-end model. In these models, price is the amount that customers pay and is considered a sacrifice; thus, it is related negatively to perceived savings. A price discount, on the other hand, is a reduction from the original price and is perceived as a gain (Monroe 2003; Munger and Grewal 2001); therefore, it is related positively to perceived savings. Accordingly, Hypothesis 1 was proposed as below (see Fig. 1):

Hypothesis 1 A price discount has a positive influence on perceived savings. Apparel consumers' perceived savings increase as the price discount increases.

\section{Informational effects of price discounts}

In addition to economic effects of price discounts, price discounts also have informational effects, which can be defined as the effects created by the communication of direct or inferential knowledge derived from exposure to a price discount (Raghubir et al. 2004). A common informational route of promotion effect is quality inference. Raghubir 


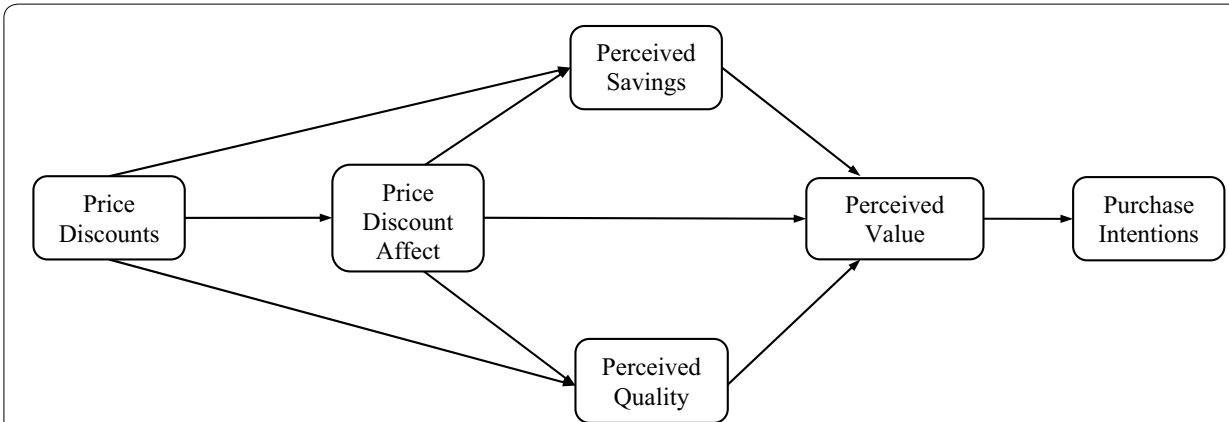

Fig. 1 Research model

et al. (2004) suggested a negative relationship between a price discount and perceived quality. Customers tend to infer that a discounted product is low in quality, especially when they receive an unexpectedly high price discount that other retailers typically do not offer. However, previous studies showed inconsistent results on the relationship between price discounts and perceived quality. Price discounts might increase perceived quality (Huang et al. 2014), decrease perceived quality (Garretson and Clow 1999), or have no effect on perceived quality (Grewal et al. 1998a).

According to Zeithaml (1988), when the product quality is difficult to evaluate at purchase, consumers' perceived quality depends more on extrinsic product attributes than on intrinsic product attributes. Extrinsic product attributes are not physical parts of the product, but product-related cues (e.g., price, brand, and level of advertising), while intrinsic product attributes are physical properties of the product (e.g., color and textures). If consumers cannot predict the service quality before the service, such as dental service (Garretson and Clow 1999), they would expect quality based on the price that they pay. A high price discount signals to consumers that they may receive a low quality service. On the other hand, if consumers can expect the product quality (for example, at Starbucks, the same coffee is served to everyone all the time whether a price promotion is used or not; Huang et al. 2014), they would be excited to receive a price promotion, and a positive evaluation would result.

In the case of online apparel shopping, it is difficult for online shoppers to examine the apparel quality at the time of purchase because fit and textures, which are important criteria to evaluate apparel products, are not available. Consumers would be more likely to use extrinsic cues (e.g., price discounts) rather than intrinsic cues (e.g., fit and textures) to evaluate the quality of apparel products; price promotion would be a strong cue to infer the apparel quality online. A high price discount may signal to online apparel shoppers that the product is of low quality. This proposition is consistent with the pricequality-value model and means-end model, in which price and perceived quality have a positive relationship (Monroe 2003; Sweeney et al. 1999; Zeithaml 1988). As a reduction from the original price, a price discount is related negatively to perceived quality. Accordingly, Hypothesis 2 was proposed:

Hypothesis 2 A price discount has a negative influence on perceived quality. Apparel consumers' perceived quality decreases as the price discount increases. 


\section{Affective effects of price discounts}

Affect is a term frequently used in marketing research to indicate a general category of feelings, including emotions and moods (Bagozzi et al. 1999). In particular, the affective effects of price discounts are the feelings and emotions aroused by receiving or missing a promotion (Raghubir et al. 2004). Price discount affect in the current study is specified as the feelings aroused by a price discount. The affective route of promotion effects also can be positive or negative. Examples of positive affective effects are consumers' enjoyment or excitement from searching for the best bargains (Cox et al. 2005), consumers' feelings that they are smart or lucky when they find a deal (Peine et al. 2009), or a sense of accomplishment when consumers pay a reduced price (Mano and Elliott 1997). On the other hand, consumers may feel regretful when they miss a deal or jealous when special offers are available only for certain customers, such as new customers (Raghubir et al. 2004). Honea and Dahl (2005) and Peine et al. (2009) found that promotion increased customers' positive affect, such as happiness. Customers felt proud of themselves as smart shoppers when they took advantage of an offer. Schindler (1998) also found that price promotion could make customers feel excited and powerful. According to these previous studies, a price discount is expected to increase consumers' positive affect.

Hypothesis 3 A price discount has a positive influence on price discount affect. Apparel consumers' positive affective feelings increase as the price discount increases.

\section{Affect and perceived savings}

The affect-as-information model (Clore et al. 2001) indicates that affective feelings as a component of input in information processing can provide information and serve as crucial cues to guide judgment and decision making; therefore, affective feelings can lead to a higher or lower evaluation of a certain object. No study has examined the effect of affect on perceived savings, but some studies may have brought some lights about this relationship. Hsu and Liu (1998) investigated the role of mood in price promotions and found that the effect of price promotion (advertised selling price) on perceived transaction value (the evaluation of satisfaction obtained from taking advantage of the price deal) was moderated by buyers' mood states. When encountering price promotions, buyers in a positive mood will perceive a greater transaction value than buyers in a negative mood, indicating that positive affect has a positive influence on consumers' perception of price deal and therefore may positively influence perceived savings. Heussler et al. (2009) examined the effect of affect on perceived price fairness and found that positive emotions could compensate for the negative impact of price increases on perceived price fairness, indicating that positive affect has a positive influence on consumers' perceptions of price change and therefore may positively influence perceived savings. According to the affect-as-information model and above studies, consumers who have greater positive affective feelings aroused by a price discount are expected to perceive a greater amount of savings.

Hypothesis 4 Price discount affect has a positive influence on perceived savings. Apparel consumers' perception of savings increases as the price discount affect increases. 


\section{Affect and perceived quality}

The affect-as-information model (Clore et al. 2001) can also support the effect of affective feelings on consumers' perception of product quality. Consumers use affect as an input in their information processing when they evaluate product quality. O'Neill and Lamber (2001) found that price affect had a positive influence on price-quality inferences. The participants who found greater enjoyment in the prices of athletic shoes expressed a stronger belief that a higher price is an indication of a higher level of quality. Chebat et al. (1995) examined the influence of affect on perception of service quality in a bank and also found that the higher the level of pleasure, the higher the level of perceived service quality in personnel's empathy and assurance. Kempf (1999) investigated the role of affect in the evaluation of hedonic product trials and found that affective responses, such as pleasure and arousal, were significant antecedents of the participants' evaluations of the trial experience. When these research results are applied to the context of price discounts for apparel products, consumers who have greater positive affect aroused by a price discount are expected to perceive higher product quality.

Hypothesis 5 Price discount affect has a positive influence on perceived quality. Apparel consumers' perception of product quality increases as the price discount affect increases.

\section{Affect and perceived value}

Perceived value in general is the worth that a product has in the mind of the consumer. Sweeney and Soutar (2001) investigated the constructs for value creation and showed four factors for the perceived value: quality, emotional, price, and social value. The authors considered quality and emotion as sub-dimensions of perceived value. However, in the current study, the perceived value refers to only the price dimension of perceived value because the majority of studies on pricing define value as the value for money and use perceived value as a separate construct from perceived quality and emotion (e.g., Dumana and Mattilab 2005; Hsee and Rottenstreich 2004; Teas and Agarwal 2000). The current study proposes that price discount affect has a positive influence on the price dimension of perceived value identified by Sweeney and Soutar (2001).

In marketing research, the most frequently used theoretical models to investigate the relationship between price and perceived value, such as the price-quality-value model (Monroe and Krishnan 1985) and the means-end model (Zeithaml 1988), are in a cognitive approach. However, Holbrook and Hirschman (1982) argued that most human beings are intrinsically pleasure seeking. In many situations when consumers make purchase decisions, they seek affective benefits, such as arousal, excitement, and stimulation. In addition to the affect-as-information model (Clore et al. 2001), which can support the effect of affect on perceived value, the affect heuristic also supports the importance of affect in perceived value. The affect heuristic (Slovic et al. 2007) indicates that emotion can be used as a mental shortcut that allows people to make decisions and solve problems quickly and efficiently. In the context of price discounts, Aydinli et al. (2014) found that price promotion lowered consumers' motivation to use mental effort. When a price promotion is offered, consumers are more likely to depend on affect than on extensive information processing (recalling product information and spending time considering choice options) to make a quicker and easier purchase decision. 
Prior studies supported the effect of affect on perceived value (Dumana and Mattilab 2005; Hsee and Rottenstreich 2004). Dumana and Mattilab (2005) found that affective factors (hedonics and pleasure) were strongly linked to cruise vacationers' perceptions of value. Hsee and Rottenstreich (2004) found that when people relied on feeling to evaluate value, they were sensitive to the presence or absence of a stimulus (e.g., price discount), but were insensitive to further variations of scope (e.g., number of products in a set). The participants who were encouraged to evaluate value by feeling were willing to pay more for a $5-C D$ set than those who were encouraged to evaluate value by calculation. However, for a 10-CD set, the participants who were encouraged to evaluate value by feeling were insensitive to the number of $\mathrm{CDs}$ available in the set and were willing to pay less than those who were encouraged to evaluate value by calculation, supporting that feeling plays an important role in perceived value. Therefore, according to the affect-as-information model (Clore et al. 2001), the affect heuristic (Slovic et al. 2007), and prior studies (Aydinli et al. 2014; Dumana and Mattilab 2005; Hsee and Rottenstreich 2004), apparel consumers who have a greater positive affect aroused by the price discount are expected to perceive the value for money to be higher.

Hypothesis 6 Price discount affect has a positive influence on perceived value. Apparel consumers' perception of value increases as the price discount affect increases.

\section{Mediating effect of price discount affect}

From Hypothesis 3 to Hypothesis 6, the relationships between price discounts and price discount affect (H3), price discount affect and perceived savings (H4), price discount affect and perceived quality (H5), and price discount affect and perceived value (H6) were examined. Here Hypothesis 7 was proposed to examine the mediating effect of price discount affect on the relationships between price discount and three cognitive evaluations (i.e., perceived savings, perceived quality, and perceived value).

Previous studies showed that consumers' affect induced by an external stimulus influences cognitive evaluation (Isen et al. 1978; Obermiller and Bitner 1984; O'Neill and Lamber 2001). Under conditions with limited information, such as online shopping, affective responses are more likely to influence consumers' judgments than cognitive responses (Shiv and Fedorikhin 1999; Zeithaml 1988). Consumers would react first with affective responses as a lower order reaction than a cognitive reaction, and then their cognitive reaction would be influenced by their affective responses (Campbell 2007; Shiv and Fedorikhin 1999; Zeithaml 1988). Furthermore, Zeithaml (1988) argued that perceived quality has two forms-affective quality and cognitive quality. Affective quality is more related to nondurable products and experience goods, while cognitive quality, which needs a higher level of cognitive judgment, is more associated with durable and searching goods. Because apparel is a nondurable and experience good, consumers would be more likely to evaluate the product quality according to their affective status; the affect would influence their cognitive evaluations.

According to these previous studies, in the online apparel shopping context of the current study, price discounts are expected to increase positive affect, and the increase in positive affect increases positive cognitive evaluations (i.e., perceived savings, perceived quality, and perceived value). Therefore, price discount affect was proposed as a mediator (a) between price discounts and perceived savings, (b) between price discounts and 
perceived quality, and (c) between price discounts and perceived product value. Accordingly, Hypothesis 7 was proposed as follows:

Hypothesis 7 Affect mediates the effect of price discounts on (a) perceived savings, (b) perceived product quality, and (c) perceived product value. A price discount increases apparel consumers' positive affect, and this increase in positive affect in turn increases consumers' (a) perceived savings, (b) perceived quality, and (c) perceived value.

\section{Perceived savings and perceived value}

The price-quality-value model and means-end model propose that the trade-off between perceived quality and perceived sacrifice (the perception of paying the cost) results in perceived value (Monroe and Krishnan 1985). Accordingly, perceived sacrifice and perceived value have a negative relationship, and perceived savings and perceived value have a positive relationship. The findings of previous studies have supported these relationships. Grewal et al. (1998b) and Teas and Agarwal (2000) found that a higher level of perceived sacrifice led to a lower level of perceived value. Choi et al. (2010) examined a price discount and a "Scratch and Save" type of price promotions and found that the expected savings positively influenced perceived value, supporting that perceived savings enhanced consumers' perceptions of value.

Hypothesis 8 Perceived savings have a positive influence on perceived value. Apparel consumers' perception of value increases as perceived savings increase.

\section{Perceived quality and perceived value}

The price-quality-value model (Monroe and Krishnan 1985) and means-end model (Zeithaml 1988) propose that perceived quality can directly influence perceived value. The findings of previous studies have supported the positive relationship between perceived quality and perceived value. For example, Teas and Agarwal (2000) found that the relationship between price and perceived value is mediated by perceived quality. The perceived quality directly influences the value perceived by consumers. Grewal et al. (1998b) also found a positive relationship between buyers' perceived quality and perceived value. According to the price-quality-value model, the means-end model, and these previous studies, the following hypothesis was proposed:

Hypothesis 9 Perceived quality has a positive influence on perceived value. Apparel consumers' perception of value increases as perceived quality increases.

\section{Perceived value and purchase intentions}

The price-quality-value model (Monroe 2003) and means-end model (Zeithaml 1988) support the positive relationship between perceived value and purchase intentions, and previous studies have also shown evidence supporting this relationship (Kwon et al. 2007; Yang and Peterson 2004). Yang and Peterson (2004) studied online shopping behaviors and found a positive effect of perceived value on online shoppers' loyalty. Kwon et al. (2007) examined the mediating role of perceived value in the relationship between team identification and purchase intention of team-licensed apparel. They found that team identification alone did not lead to purchase intentions; perceived value fully meditated this relationship, supporting the importance of the influence of perceived value on purchase intentions. Accordingly, the following hypothesis was proposed: 
Hypothesis 10 Perceived value has a positive influence on purchase intentions. Apparel consumers' purchase intentions increase as perceived value increases.

\section{Methods}

A between-subjects experimental design was used to investigate the proposed model and test the hypotheses. The price discounts were manipulated at four levels: 10, 30, 50, and $70 \%$. Jeans were selected as the product stimulus, web pages were developed to create a fictional online store, and an online survey was used for data collection.

\section{Stimulus selection and development}

\section{Product selection}

Jeans were selected as the product stimulus because people of all genders, ages, and social classes wear jeans (Miller 2013). Consumers in the United States are familiar with this product and have experience wearing and purchasing them. According to Foreman (2015), the average annual denim consumption is four pairs of jeans per person in the United States. A preliminary survey was conducted to select a pair of jeans with a basic style for the study. Three styles of jeans (straight, wide, and skinny) without any extra design, embroidery, or logo were selected for male and female, resulting in a total of six pairs of jeans. The colors of the jeans were made similar with Adobe Photoshop adjustments.

Amazon Mechanical Turk (MTurk) was used to distribute the survey and collect the data. Three styles of female or male jeans were shown to each participant. The images of the three styles of jeans appeared in a random order for each participant to reduce the order effects. Then each participant was instructed to assess the likeability of each style of jeans on a 7-point Likert scale (bad-good, unpleasant-pleasant, unlikable-likable, unflattering-flattering, unattractive-attractive, and not stylish-stylish; Cox and Cox 2002). A total of 50 usable responses were collected.

Since consumers' decisions of apparel purchasing primarily rely on aesthetics, such as clothing style (Dutton and Istook 2006; Eckman et al. 1990), without positive perceptions of clothing style, consumers are less likely to purchase the product, and price may have little or no impact on their purchase behavior. In addition, different jeans images were provided for male and female due to gender differences. For these reasons, two criteria were applied to select the style of jeans: (a) a style that had a positive rating in likability (an average rating of 4 or higher on a 7-point Likert scale) and (b) a style that was not significantly different in likability across genders. The results showed that only the straight style jeans received ratings above 4 for both male and female jeans (Male: $M_{\text {straight }}=5.03, M_{\text {wide }}=2.91$, and $M_{\text {skinny }}=3.21$; Female: $M_{\text {straight }}=5.04, M_{\text {wide }}=2.77$, and $\left.M_{\text {skinny }}=4.90\right)$. The results of a $t$ test showed that there was no significant difference in likability between the male and female straight jeans $(p=.99)$. According to these results, the straight jeans were selected for the study.

\section{Original retail price}

Five American jeans brands (i.e., Levi's, Wrangler, Calvin Klein Jeans, 7 For All Mankind, and Guess) were selected to set the original retail price of the jeans. These five brands are especially popular in the United States for both men and women, according to the "Top 
10 Best Selling Jeans Brands 2016-2017" (Aslam 2017). The retail prices of the basic straight jeans of these five brands were averaged, and the average price of $\$ 68$ was set as the original price of the jeans in the study.

\section{Web page development}

Web pages were developed to create a fictional online store and used for the data collection. On the first web page, the purpose of the study and the confidentiality disclosure information were provided for the participants to decide whether they would participate in the survey. On the second web page, an experimental scenario was provided, and the participants were directed to role play that (a) they were considering buying a new pair of jeans, (b) they found a website that was selling jeans, and (c) a certain pair of jeans on the website was on sale. The third webpage showed images and information about a fictional online store, including an image of the pair of jeans on sale, a description of the jeans on sale, a size list, one of the randomly assigned price discounts $(10,30,50$, or $70 \%)$, the original retail price $(\$ 68.00)$, the selling price after the $10,30,50$, or $70 \%$ discount ( $\$ 61.20, \$ 47.60, \$ 34.00$, or $\$ 20.40$ ), and fictitious brand and retailer names, which were used to avoid any confounding effects. Beneath the images and information on the web page, an instruction was given to ask the participants to read the information, view the image carefully, and then answer the questions.

\section{Measures}

A questionnaire was developed to measure the dependent variables (i.e., perceived savings, perceived quality, perceived value, affect, and purchase intentions). All the measures are shown in Table 1 . These measures were selected because they are commonly used in pricing studies, and the reliability of the scales has been well established. Perceived savings were measured by three items from Biswas and Burton (1993), perceived quality was measured by four items from Sweeney et al. (1999), and perceived value was measured by three items from Urbany et al. (1988). Price discount affect was measured by six semantic differential measures on a 7-point bipolar response scale (Mehrabian and Russell 1974), a scale that has been widely used by numerous scholars for several decades. Purchase intentions were measured by three items from Sweeney et al. (1999). All questions were modified to fit the purpose of the study, and all items, except the items for price discount affect, were measured on a 7-point Likert scale.

\section{Data collection}

Participants were recruited by a research firm in the United States, and an online survey was used for the data collection. To control the variance attributable to gender, the numbers of male and female participants were kept the same at each price discount level. With this gender distribution in mind, we assigned the participants randomly to one of the four levels of product discount and asked them about their perceived savings, perceived quality, perceived value, price discount affect, and purchase intentions based on the price discount assigned. A total of 209 usable responses were collected. The sample size was determined by power analysis for structural equation modeling (MacCallum et al. 1996). With over 100 degrees of freedom, the minimum sample size was 132 to 
Table 1 Measure items and confirmatory factor analysis results

\begin{tabular}{|c|c|c|c|c|}
\hline Factor/item & Factor loading & CR & AVE & $\begin{array}{l}\text { Cronbach's } \\
\text { alpha }\end{array}$ \\
\hline Perceived savings & & .94 & .85 & .93 \\
\hline $\begin{array}{l}\text { The amount of discount offered on the pair of jeans represents large } \\
\text { savings }\end{array}$ & .91 & & & \\
\hline $\begin{array}{l}\text { The amount of money that customers would save on the pair of } \\
\text { jeans is very large }\end{array}$ & .93 & & & \\
\hline The amount of discount stated for the pair of jeans is very high & .93 & & & \\
\hline Perceived quality & & .92 & .73 & .92 \\
\hline This pair of jeans would be reliable & .86 & & & \\
\hline This pair of jeans would be dependable & .86 & & & \\
\hline This pair of jeans would be durable & .89 & & & \\
\hline The workmanship on this pair of jeans would be good & .81 & & & \\
\hline Perceived value & & .93 & .87 & .93 \\
\hline This pair of jeans is a good value for the money & .94 & & & \\
\hline This pair of jeans is a good buy & .93 & & & \\
\hline At the price shown, this pair of jeans is economical ${ }^{\mathrm{a}}$ & .49 & & & \\
\hline Price discount affect & & .92 & .73 & .91 \\
\hline \multicolumn{5}{|l|}{ How do you feel after seeing this price discount? } \\
\hline Happy-unhappy & .92 & & & \\
\hline Pleased-annoyed & .93 & & & \\
\hline Content-melancholic & .77 & & & \\
\hline Excited-calm & .79 & & & \\
\hline Aroused-unaroused ${ }^{\mathrm{a}}$ & .49 & & & \\
\hline Stimulated-relaxed ${ }^{\mathrm{a}}$ & .48 & & & \\
\hline Purchase intentions & & .96 & .90 & .96 \\
\hline I would consider buying this pair of jeans with this price discount & .93 & & & \\
\hline $\begin{array}{l}\text { There is a strong likelihood that I would buy this pair of jeans with } \\
\text { this price discount }\end{array}$ & .95 & & & \\
\hline I would purchase this pair of jeans with this price discount & .96 & & & \\
\hline
\end{tabular}

The values of $C R, A V E$, and Cronbach's alpha shown in the table were calculated after the three items were removed

$\mathrm{CR}$, composite reliability; AVE, average variance extracted

a These three items were removed because the factor loadings were smaller than .50

achieve a power of .80 . Thus, 200 responses were set as the target sample size, and 209 responses were received.

\section{Results}

\section{Participants}

The participants ranged in age from 18 to 54, and the largest age group was 25-34 (39.7\%). Self-identified genders were $48.3 \%$ males and $49.3 \%$ females. Most participants were Caucasian (74.6\%), followed by Asian or Pacific Islander (11.5\%), and African American or Black (6.7\%). Half of the participants were married (50.7\%), while nearly one-third was single (31.6\%). The majority of the participants had a college degree (43.5\%; see Table 2). 
Table 2 Demographic characteristics

\begin{tabular}{|c|c|c|c|}
\hline Demographic & Categories & $\begin{array}{l}\text { Frequency } \\
\left(\mathrm{N}=204^{\mathrm{a}}\right)\end{array}$ & Percent \\
\hline \multirow[t]{4}{*}{ Age } & $18-24$ & 30 & 14.7 \\
\hline & $25-34$ & 81 & 39.7 \\
\hline & $35-44$ & 64 & 31.4 \\
\hline & $45-54$ & 29 & 14.2 \\
\hline \multirow[t]{2}{*}{ Gender } & Male & 101 & 48.3 \\
\hline & Female & 103 & 49.3 \\
\hline \multirow[t]{6}{*}{ Ethnic background } & African American or Black & 14 & 6.7 \\
\hline & Caucasian or White & 158 & 74.6 \\
\hline & Hispanic, Latino or Spanish Origin & 8 & 3.8 \\
\hline & American Indian or Alaska Native & 1 & .5 \\
\hline & Asian or Pacific Islander & 24 & 11.5 \\
\hline & Others & 1 & .5 \\
\hline \multirow[t]{4}{*}{ Marital status } & Single & 68 & 31.6 \\
\hline & Divorced & 12 & 5.7 \\
\hline & Married & 106 & 50.7 \\
\hline & Cohabitation & 20 & 9.6 \\
\hline \multirow[t]{7}{*}{ Education } & High School or Equivalent & 4 & 1.9 \\
\hline & Vocational/Technical School (2 year) & 11 & 5.3 \\
\hline & Some College & 68 & 32.5 \\
\hline & College Graduate (4 year) & 91 & 43.5 \\
\hline & Master's Degree (MS) & 22 & 10.5 \\
\hline & Doctoral Degree (Ph.D.) & 2 & 1.0 \\
\hline & Professional Degree (MD, JD, etc.) & 6 & 2.9 \\
\hline \multirow[t]{6}{*}{ Discretionary budget } & $<\$ 100$ & 32 & 15.3 \\
\hline & $\$ 100-249$ & 55 & 26.3 \\
\hline & $\$ 250-499$ & 50 & 23.9 \\
\hline & $\$ 500-749$ & 26 & 12.4 \\
\hline & $\$ 750-999$ & 19 & 9.1 \\
\hline & $>\$ 1000$ & 22 & 10.5 \\
\hline
\end{tabular}

a Total number of participants was 209; number of missing responses was 5

Validity and reliability check

The measurement model was assessed by using confirmatory factor analysis (CFA), and the results are shown in Table 1 . The exogenous variable was price discounts and the endogenous latent constructs were perceived savings, perceived quality, perceived value, price discount affect, and purchase intentions. Two items in price discount affect and one item in perceived value were removed because the standardized factor loadings were less than .5 (Hair et al. 2010). According to the fit criteria suggested by Hair et al. (2010) and $\mathrm{Hu}$ and Bentler (1999), the Chi squared/degrees of freedom ratio should be $\leq 2$, CFI and NFI $\geq .95$, GFI and AGFI $\geq .90$, and RMSEA $\leq .06$ to indicate a good fit of the data. The goodness-of-fit statistics obtained indicated that the measurement model fit the data well: $\chi^{2} / d f=1.96, \mathrm{CFI}=.98, \mathrm{NFI}=.96, \mathrm{GFI}=.92, \mathrm{AGFI}=.90$, and $\mathrm{RMSEA}=.06$.

The convergent validity of the measures in the study was supported by three evaluations: (a) all factor loadings were between .77 and .96, greater than the recommended minimum value of .50 (Table 1), (b) the average variance extracted (AVE) for each construct ranged from .73 to .90 , greater than the recommended minimum value of .50 , and 


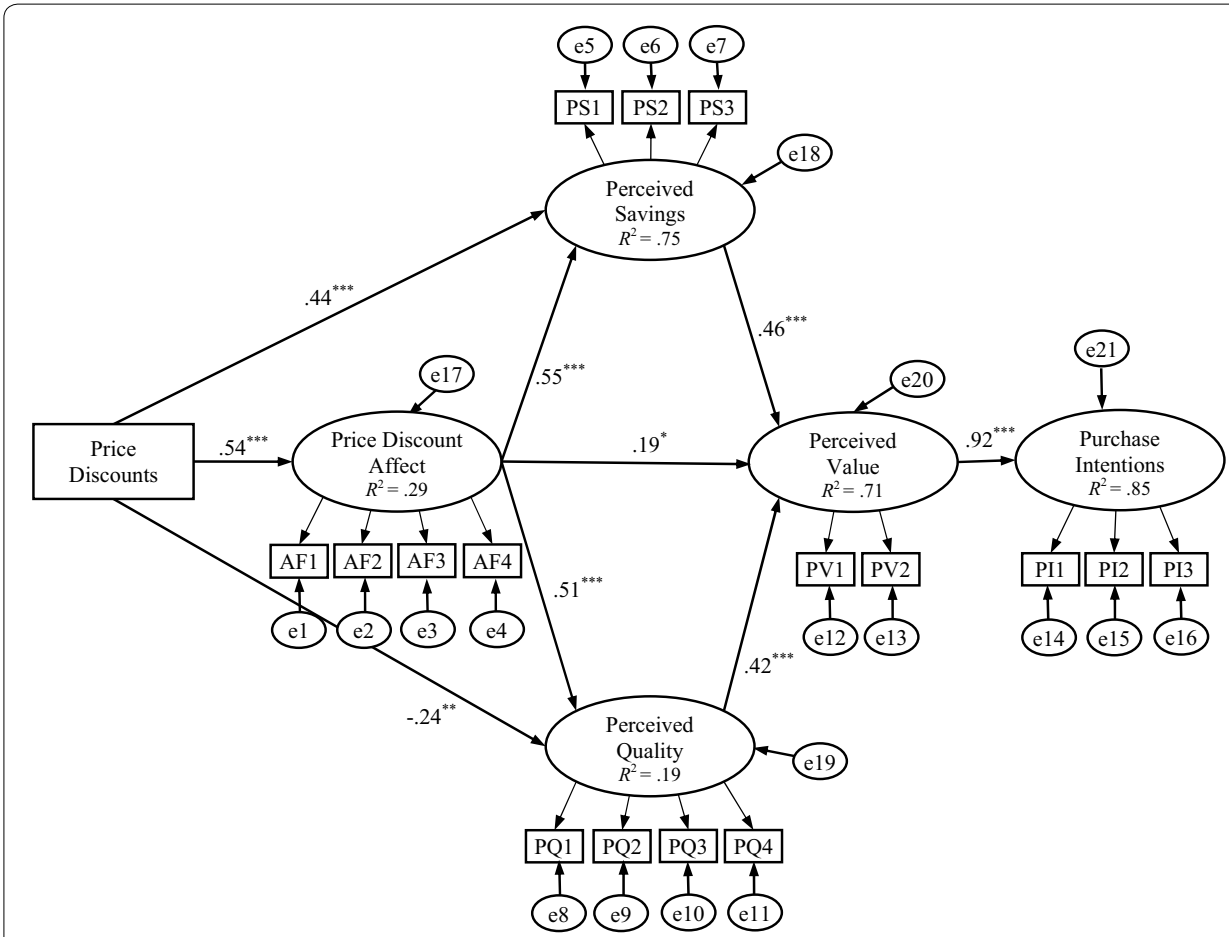

Fig. 2 Structural model and hypothesis testing results. All path coefficients are standardized estimates; ${ }^{*} p \leq .05,{ }^{* *} p \leq .01,{ }^{* * *} p \leq .001$

(c) the composite reliability (CR) for each construct ranged from .92 to .96 , exceeding the recommended minimum value of .70. The square root of the AVE was larger than the corresponding correlation coefficient between the factors, confirming discriminant validity (see Table 3). All minimum values were based on the recommendations of Hair et al. (2010).

\section{Structural equation modeling and hypothesis testing}

Structural equation modeling was conducted with maximum likelihood extraction to test the proposed hypotheses, and the results are shown in Fig. 2. The goodness of fit statistics were $\chi^{2} / d f=1.59, \mathrm{CFI}=.98, \mathrm{NFI}=.95, \mathrm{GFI}=.91$, AGFI $=.90$, and RMSEA $=.05$, indicating that the proposed model fit the data well (Hu and Bentler 1999). The price discounts explained $29.4 \%$ of the variance in affect $\left(R^{2}=.29\right)$, while the price discounts

Table 3 Discriminant validity of measurement model

\begin{tabular}{llllll}
\hline & $\begin{array}{l}\text { Perceived } \\
\text { savings }\end{array}$ & $\begin{array}{l}\text { Perceived } \\
\text { quality }\end{array}$ & $\begin{array}{l}\text { Price discount } \\
\text { affect }\end{array}$ & $\begin{array}{l}\text { Perceived } \\
\text { value }\end{array}$ & $\begin{array}{l}\text { Purchase } \\
\text { intentions }\end{array}$ \\
\hline Perceived savings & $.92^{\mathrm{a}}$ & & & & \\
Perceived quality & .24 & $.85^{\mathrm{a}}$ & & & \\
Price discount affect & .80 & .40 & $.86^{\mathrm{a}}$ & $.93^{\mathrm{a}}$ & \\
Perceived value & .72 & .60 & .75 & .90 & $.95^{\mathrm{a}}$ \\
Purchase intentions & .60 & .64 & .67 & & \\
\hline
\end{tabular}

a Square root of the AVE value for each construct 
Table 4 Standardized coefficients of direct, indirect, and total effects

\begin{tabular}{lcll}
\hline & $\begin{array}{l}\text { Direct effects } \\
\text { estimate }\end{array}$ & $\begin{array}{l}\text { Indirect effects } \\
\text { estimate }\end{array}$ & $\begin{array}{l}\text { Total } \\
\text { effects } \\
\text { estimate }\end{array}$ \\
\hline Price discounts $\rightarrow$ perceived savings & $.44^{* *}$ & $.30^{* *}$ & $.73^{* *}$ \\
Price discounts $\rightarrow$ perceived quality & $-.24^{* *}$ & $.28^{* *}$ & .04 \\
Price discounts $\rightarrow$ affect & $.54^{* *}$ & .00 & $.54^{* *}$ \\
Price discounts $\rightarrow$ perceived value & .00 & $.49^{* *}$ & $.49^{* *}$ \\
Affect $\rightarrow$ perceived savings & $.55^{* *}$ & .00 & $.55^{* *}$ \\
Affect $\rightarrow$ perceived quality & $.51^{* *}$ & .00 & $.51^{* *}$ \\
Affect $\rightarrow$ perceived value & $.19^{*}$ & $.47^{* *}$ & $.67^{* *}$ \\
Perceived savings $\rightarrow$ perceived value & $.46^{* *}$ & .00 & $.46^{* *}$ \\
Perceived quality $\rightarrow$ perceived value & $.42^{* *}$ & .00 & $.42^{* *}$ \\
Perceived value $\rightarrow$ purchase intentions & $.92^{* *}$ & .00 & $.92^{* *}$ \\
\hline
\end{tabular}

${ }^{*} p \leq .05,{ }^{* *} p \leq .01$

and price discount affect explained $74.9 \%$ of the variance in perceived savings and $18.7 \%$ of the variance in perceived quality. Perceived savings, perceived quality, and price discount affect explained $70.9 \%$ of the variance in perceived value. Furthermore, perceived value explained $84.8 \%$ of the variance in purchase intentions.

These results supported all the hypotheses proposed. Price discounts had a positive influence on perceived savings ( $\mathrm{H} 1: \beta=.44, t=8.47, p<.001)$, a negative influence on perceived quality $(\mathrm{H} 2: \beta=-.24, t=-2.87, p<.01)$, and a positive influence on price discount affect (H3: $\beta=.54, t=8.62, p<.001$ ). Price discount affect had a positive influence on perceived savings ( $\mathrm{H} 4: \beta=.55, t=9.87, p<.001)$, a positive influence on perceived quality (H5: $\beta=.51, t=5.82, p<.001)$, and a positive influence on perceived value $(\mathrm{H} 6: \beta=.19, t=2.20, p<.05)$.

The mediating effect of affect was analyzed by using the bootstrapping method (see Table 4). There were significant indirect effects of price discounts on perceived savings (H7a: $\beta=.30, p<.01)$ and on perceived quality (H7b: $\beta=.28, p<.01)$ through price discount affect. There was a significant indirect effect of price discounts on perceived value through (a) perceived savings, (b) perceived quality, and (c) price discount affect $(\beta=.47, p<.01)$. To identify whether there was a significant indirect effect of price discounts on perceived value through price discount affect alone, the standardized coefficient was calculated according to Shrout and Bolger (2002). The standardized coefficient of the direct effect of price discounts on price discount affect (.54) was multiplied by the standardized coefficient of the direct effect of price discount affect on perceived value (.19), and the result was $.54 \times .19=.10(p=.05)$, indicating a significant indirect effect (H7c). Significant total effects were found in all the paths, except the total effect of price discounts on perceived quality.

As proposed in $\mathrm{H} 8$ and $\mathrm{H} 9$, perceived value was affected positively by perceived savings (H8: $\beta=.46, t=5.49, p<.001)$ and perceived quality $(\mathrm{H} 9: \beta=.42, t=7.66, p<.001$; see Fig. 2). Lastly, perceived value had a positive influence on purchase intentions (H10: $\beta=.92, t=19.24, p<.001)$. 


\section{Discussion}

Consistent with the price-quality-value model (Monroe and Krishnan 1985) and means-end model (Zeithaml 1988), the results indicated that as price discounts increased, consumers perceived larger monetary savings, but lower product quality. Furthermore, consistent with previous studies (Honea and Dahl 2005; Schindler 1998), positive affect increased as price discounts increased; price discounts apparently cause consumers to have positive feelings, such as happiness, pleasure, contentment, and excitement.

A unique finding of this study was that the direct effect of price discounts on affect was stronger than that on perceived savings or on perceived quality. A comparison of the three types of price promotion effects identified by Raghubir et al. (2004) indicated that the affective effect of price discounts (i.e., the effect of price discounts on affect) is stronger than economic effect (i.e., the effect of price discounts on perceived savings) or informational effect (i.e., the effect of price discounts on perceived quality), particularly in the context of an online apparel product. Consumers perceived high hedonic value not only in the apparel products themselves (Kim and Forsythe 2007; Kim and Hong 2011), but also in the price discount they received. In addition, due to the limited information on online shopping, consumers rely more on affective reaction than on cognitive evaluations in the formation of their perceptions (Zeithaml 1988). These results indicate that price discounts play an important role in creating an affective shopping experience for online apparel shoppers.

In addition to a strong direct relationship between price discounts and price discount affect, the results also showed a significant mediating effect of price discount affect on the relationship between price discounts and perceived quality. When the direct effect of price discounts on perceived quality was examined, the results showed a negative relationship; i.e., consumers perceived that highly discounted products were of low quality. However, when price discount affect served as a mediator, the indirect relationship between price discounts and perceived quality became positive; i.e., the affect created by a price discount led to a positive perception of product quality. According to Lee and Tsai (2014), when consumers use their emotions rather than cognition to evaluate products or make purchase decisions, they pay less attention to the details and nuance, but focus instead on their affective experience, probably because affect can change the effect of price discounts on perceived quality from negative to positive. These results support the affect-cognition model in that the affect triggered by a particular stimulus influences consumers' cognitive responses.

Lastly, the findings from this study revealed that apparel consumers who perceived a high level of savings and product quality were likely to perceive that the product had a high value. The perception of high value in turn led to a high level of purchase intentions. These findings confirmed the price-quality-value model (Monroe and Krishnan 1985) and means-end model (Zeithaml 1988), suggesting that perceived savings and perceived quality are predictors of perceived value. Furthermore, this study showed that perceived value alone explained $85 \%$ of the variance in purchase intentions, indicating that perceived value is a strong predictor of purchase intentions. 


\section{Conclusion}

\section{Academic contributions}

The purpose of the study was to investigate the mediating effects of price discount affect on the relationships between price discounts and customers' perceptions (i.e., perceived savings, quality, and value) and the effect of perceived value on purchase intentions in an apparel online shopping context. To achieve this objective, we developed a conceptual model by extending the price-quality-value model (Monroe and Krishnan 1985) and means-end model (Zeithaml 1988) and integrating the concepts of the three promotion effects (economic, informational, and affective effects; Raghubir et al. 2004) and the concept of the affect-cognition model. By considering the influences of price discount affect, the proposed model provides a better understanding of the effects of price discounts on apparel consumers' perceptions of savings, quality, and value and contributes to the current price discount literature.

The most intriguing result in this study was that the direct and indirect influences of price discounts on perceived apparel quality were both significant, but opposite in direction, resulting in an insignificant total effect. The results of the negative direct effect of price discounts on perceived quality may explain why some previous researchers have found a negative effect of price discounts on perceived quality (Garretson and Clow 1999), while the results of the positive indirect effect of price discounts on perceived quality may explain why some other researchers have found a positive effect (Huang et al. 2014; Rungtrakulchai 2013). In addition, the total effect of price discounts on perceived quality was not significant in this study because the opposite direct and indirect effects cancelled each other out. The phenomenon that direct and indirect effects are in opposite directions is referred to as competitive mediation (Shrout and Bolger 2002). These results may explain why a previous study (Grewal et al. 1998a) found that price discounts had no significant influence on perceived quality.

By demonstrating the important mediating role of affect in the effect of price discounts on cognitive perceptions, this study contributes to the understanding of the relationships between affect and cognitions in the formation of consumers' perceptions, particularly focusing on online apparel shopping. There has been no consensus on whether cognition influences affect or affect influences cognition (Campbell 2007; Chebat and Michon 2003; Peine et al. 2009; Shiv and Fedorikhin 1999). As we found that the affective effect of price discounts is greater than cognitive effects (economic and informational effects), the current research confirmed that the affect-cognition model is more appropriate than the cognition-affect model to explain price discount effects in the context of online apparel shopping. Our results suggest that due to the limited information provided in online shopping and the hedonic nature of apparel products, consumers process cognitive perceptions according to affective status, which is a spontaneous manner from price discounts.

\section{Managerial implications}

In addition to extending the body of literature on price promotion and the understanding of the influences of price discounts on consumers' perceptions of apparel products, the results of this study also provide research-based information for several managerial implications. Although offering a high price discount can increase consumers' 
perceptions of savings, it also has a negative effect on consumers' perceptions of apparel quality. Apparel retailers need to keep in mind that price promotions are a double-edged sword: they create both positive and negative influences on consumers' perceptions.

Our findings showed that in addition to the consideration of perceived savings and apparel quality-two important elements in consumers' cognitive processes in purchase decision making, the consideration of the role of affective feelings created by price promotion is also important. The enjoyment that consumers experience from a price discount can increase their perception of value directly and also compensate for the negative effect of a price discount on perceived quality. Therefore, when developing pricing and promotion strategies for online apparel shopping, retailers should make efforts to create pleasant affective experiences rather than focus on only monetary savings. Instead of simply stating the percentage of the price discount, retailers can find peripheral ways to present the price discount to increase consumers' pleasure. For instance, Naylor et al. (2006) found that the participants responded significantly faster when a promotion (e.g., a $10 \%$ discount) was associated with pleasant words (e.g., joy, delight) than with neutral words. Price discounts for special occasions, such as customers' birthdays or wedding anniversaries, or limited-time price discounts (i.e., flash sales) may be effective ways to create positive affective responses when consumers shop for hedonic products such as apparel.

\section{Limitations and future research}

Even though the study was designed and conducted carefully to ensure the validity of the findings, the results from this study should be interpreted with respect to its limitations. Although a national sample was recruited through a research firm, caution needs to be used in generalizing the results to the entire population of the United States. Because rewards (e.g., gift cards, merchandise) were provided to recruit the participants and all the participants were internet users, the disparity between the distribution of the general population and that of the participants needs to be taken into consideration.

To reduce the influences of extraneous variables that can affect internal validity, we developed a fictional online store in the study for data collection. Although we made efforts to simulate real world situations as closely as possible, consumer behaviors under experimentally controlled conditions may differ from behaviors in actual retailing settings. Future studies may use other research methods, such as using actual retail websites in a survey design or a case study to increase the external validity and verify the current findings. In addition, consumers' online and offline shopping behaviors may differ. In the current study, the negative informative effect of price discounts on perceptions of apparel quality might be especially strong because this study was carried out in an online apparel shopping context; consumers could not physically examine the products at purchase. In an uncertain situation, consumers may use price discounts as a signal to evaluate apparel quality. Further studies are needed to compare the effects of price discounts on consumer perceptions between online and offline apparel shopping.

We used jeans, a casual apparel item, as the product stimulus in this study because consumers in various segments are familiar with the product. However, each apparel product has its own characteristics, and consumers' responses to price discounts may vary when consumers shop for different types of apparel products. In future studies, 
researchers may examine different types of apparel items, such as dresses or suits, or products offered to different market categories, such as luxury or fast fashion products, to determine whether product type influences the effect of price discounts.

\section{Authors' contributions}

JEL and JHC carried out the online price discount studies, participated in the sequence alignment and drafted the manuscript. Both authors read and approved the final manuscript.

\section{Competing interests}

The authors declare that they have no competing interests.

Ethics approval and consent to participate

Not applicable.

\section{Publisher's Note}

Springer Nature remains neutral with regard to jurisdictional claims in published maps and institutional affiliations.

Received: 14 July 2017 Accepted: 6 February 2018

Published online: 15 February 2018

\section{References}

Aslam, H, (2017). Top 10 best selling jeans brands 2016-2017. Retrieved from http://www.strongestinworld.com/best-selli ng-jeans-brands/.

Aydinli, A., Bertini, M., \& Lambrecht, A. (2014). Price promotion for emotional impact. Journal of Marketing, 78(4), 80-96.

Bagozzi, R. P., Gopinath, M., \& Nyer, P. U. (1999). The role of emotions in marketing. Journal of the Academy of Marketing Science, 27(2), 184-206.

Berkowitz, E. N., \&Walton, J. R. (1980). Contextual influences on consumer price responses: An experimental analysis. Journal of Marketing Research, 17, 349-358.

Biswas, A., \& Burton, S. (1993). Consumer perceptions of tensile price claims in advertisements: An assessment of claim types across different discount levels. Journal of the Academy of Marketing Science, 21(3), 217-229.

Campbell, M. (2007). "Says who?!" How the source of price information and affect influence perceived price (un)fairness Journal of Marketing Research, 44(2), 261-271.

Chandon, P., Wansink, B., \& Laurent, G. (2000). A benefit congruency framework of sales promotion effectiveness. Journal of Marketing, 64(4), 65-81.

Chebat, J., Filiatrault, P., \& Gdlinas-Chebat, C. (1995). Impact of waiting attribution and consumer's mood on perceived quality. Journal of Business Research, 34, 191-196.

Chebat, J.-C., \& Michon, R. (2003). Impact of ambient odors on mall shoppers' emotions, cognition, and spending: A test of competitive causal theories. Journal of Marketing, 56, 529-539.

Chen, S.-F. S., Monroe, K. B., \& Lou, Y.-C. (1998). The effects of framing price promotion messages on consumers' perceptions and purchase intentions. Journal of Retailing, 74(3), 353-372.

Choi, S., Stanyer, M., \& Kim, M. (2010). Consumer responses to the depth and minimum claimed savings of "Scratch and Save (SAS)" promotions. Psychology \& Marketing, 27(8), 766-779.

Clore, G. L., Gasper, K., \& Garvin, E. (2001). Affect as information. In J. P. Forgas (Ed.), Handbook of affect and social cognition (pp. 121-144). Mahwah: Lawrence Erlbaum Associates Inc.

Cox, D., \& Cox, A. D. (2002). Beyond first impressions: The effects of repeated exposure on consumer liking of visually complex and simple product designs. Journal of the Academy of Marketing Science, 30(2), 119-130.

Cox, A. D., Cox, D., \& Anderson, R. D. (2005). Reassessing the pleasures of store shopping. Journal of Business Research, 58(3), 250-259.

Darke, P. R., \& Dahl, D. W. (2003). Fairness and the subjective value of a bargain. Journal of Consumer Psychology, 13, $328-338$.

Dodds, W. B., Monroe, K. B., \& Grewal, D. (1991). Effects of price, brand, and store information on buyers' product evaluations. Journal of Marketing Research, 28, 307-319.

Dorzdenko, R., \& Jensen, M. (2005). Risk and maximum acceptable discount levels. Journal of Product and Brand Management, 14(4), 264-270.

Dumana, T., \& Mattilab, A. S. (2005). The role of affective factors on perceived cruise vacation value. Tourism Management, 26, 311-323.

Dutton, K. C., \& Istook, C. (2006). Young adults' intent to purchase based on garment attriutes. Proceedings of International Textiles and Apparel Association, Consumer Behavior, 63, 54-56.

Eckman, M., Damhorst, M. L., \& Kadolph, S. J. (1990). Toward a model of the in-store purchase decision process: Consumer use of criteria for evaluating women's apparel. Clothing and Textiles Research Journal, 8(2), 13-22.

Foreman, K. (2015). Jean genie: The denim evaluation. BBC News. Retrieved from http://www.bbc.com/culture/story /20150401-jean-genie-the-denim-evolution.

Garretson, J. A., \& Clow, K. E. (1999). The influence of coupon face value on service quality expectations, risk perceptions and purchase intentions in the dental industry. Journal of Services Marketing, 13(1), 59-72.

Grewal, D., Krishnan, R., Baker, J., \& Borin, N. (1998a). The effect of store name, brand name and price discounts on consumers' evaluations and purchase intentions. Journal of Retailing, 74(3), 331-352. 
Grewal, D., Monroe, K. B., \& Krishnan, R. (1998b). The effects of price-comparison advertising on buyers' perceptions of acquisition value, transaction value and behavioral intentions. Journal of Marketing, 62(2), 46-59.

Gutman, J. (1982). A means-end chain model based on consumer categorization processes. Journal of Marketing, 46, 60-72.

Hair, J. F., Black, W. C., Babin, B. J., Anderson, R. E., \& Tatham, R. L. (2010). Multivariate data analysis (7th ed.). Upper Saddle River: Pearson-Prentice Hall.

Heussler, T., Huber, F., Meyer, F., Vollhardt, K., \& Ahlert, D. (2009). Moderating effects of emotion on the perceived fairness of price increases. Advances in Consumer Research, 36, 332-338.

Holbrook, M. B., \& Hirschman, E. C. (1982). The experiential aspects of consumption: Consumer fantasies, feelings, and fun. Journal of Consumer Research, 9, 132-140.

Honea, H., \& Dahl, D. W. (2005). The promotion affect scale: Defining the affective dimensions of promotion. Journal of Business Research, 58, 543-551.

Hsee, C. K., \& Rottenstreich, Y. (2004). Music, pandas, and muggers: On the affective psychology of value. Journal of Experimental Psychology, 133(1), 23-30.

Hsu, C., \& Liu, B. S. (1998). The role of mood in price promotions. Journal of Product \& Brand Management, 7(2), 150-160.

Hu, L. T., \& Bentler, P. M. (1999). Cutoff criteria for fit indexes in covariance structure analysis: Conventional criteria versus new alternatives. Structural Equation Modeling: a Multidisciplinary Journal, 6(1), 1-55.

Huang, H. C., Chang, Y. T., Yeh, C. Y., \& Liao, C. W. (2014). Promote the price promotion: The effects of price promotions on customer evaluations in coffee chain stores. International Journal of Contemporary Hospitality Management, 26(7), 1065-1082.

Isen, A. M., Shalker, T. E., Clark, M., \& Karp, L. (1978). Affect, accessibility of material in memory, and behavior: A cognitive loop? Journal of Personality and Social Psychology, 36, 1-12.

Jin, B., Sternquist, B., \& Koh, A. (2003). Price as hedonic shopping. Family and Consumer Sciences Research Journal, 31(4), 378-402.

Kaul, S. (2007). Hedonism and culture: Impact on shopping behaviour a research agenda. Vikalpa, 32(3), 81-89.

Kempf, D. S. (1999). Attitude formation from product trial: Distinct roles of cognition and affect for hedonic and functional products. Psychology \& Marketing, 16(1), 35-50.

Kim, J., \& Forsythe, S. (2007). Hedonic usage of product virtualization technologies in online apparel shopping. International Journal of Retail \& Distribution Management, 35(6), 502-514.

Kim, H., \& Hong, H. (2011). Fashion leadership and hedonic shopping motivations of female consumers. Clothing and Textiles Research Journal, 29(4), 314-330.

Kocas, C., \& Bohlmann, J. D. (2008). Segmented switcher and retailer pricing strategies. Journal of Marketing, 72(3), $124-142$.

Krishna, A., Briesch, R., Lehmann, D. R., \& Yuan, H. (2002). A meta-analysis of the impact of price presentation on perceived savings. Journal of Retailing, 78(2), 101-118.

Kwon, H. H., Trail, G., \& James, J. D. (2007). The mediating role of perceived value: Team identification and purchase intention of team-licensed apparel. Journal of Sport Management, 21(4), 540-554.

Lee, J. E., \& Stoel, L. (2016). An unintended consequence of exaggerated maximum-discount tensile price claims. Journal of Product \& Brand Management, 25(7), 700-709.

Lee, L., \& Tsai, C. I. (2014). How price promotions influence postpurchase consumption experience over time. Journal of Consumer Research, 40, 943-959.

MacCallum, R. C., Browne, M. W., \& Sugawara, H. M. (1996). Power analysis and determination of sample size for covariance structural modeling. Psychological Methods, 1, 130-149.

Mano, H., \& Elliott, M. (1997). Smart shopping: The origins and consequences of price savings. In D. Maclnnis \& M. Brucks (Eds.), Advances in consumer research (pp. 504-510). Provo: Association for Consumer Research.

Mehrabian, A., \& Russell, J. A. (1974). The basic emotional impact of environments. Perceptual and Motor Skills, 38(1), 283-301.

Miller, D. (2013). Consumption and its consequences. Hoboken: Wiley.

Monroe, K. B. (2003). Price and consumers' perceptions of value (3rd ed.). New York: McGraw-Hill.

Monroe, K. B., \& Krishnan, R. (1985). The effect of price on subjective product evaluation. In J. Jacoby \& J. Olson (Eds.), The perception of merchandise and store quality (pp. 209-232). Lexington: Lexington Book.

Munger, J. L., \& Grewal, D. (2001). The effects of alternative price promotional methods on consumers' product evaluations and purchase intentions. Journal of Product \& Brand Management, 10(3), 185-197.

Naylor, R. W., Raghunathan, R., \& Ramanathan, S. (2006). Promotions spontaneously induce a positive evaluative response. Journal of Consumer Psychology, 16(3), 295-305.

O'Neill, R., \& Lamber, D. R. (2001). The emotional side of price. Psychology \& Marketing, 18(3), 217-237.

Obermiller, C, \& Bitner, M.J. (1984). Store atmosphere: A peripheral cue for product evaluation. In D.C., Stewart (Ed.), American Psychological Association Annual Conference Proceedings, Consumer, Psychology Division. USA, p. 52-53.

Palma, D., de Dios Ortúzar, J., Rizzi, L. I., Guevara, C. A., Casaubon, G., \& Ma, H. (2016). Modeling choice when price is a cue for quality: A case study with Chinese wine consumers. Journal of Choice Modelling, 19, 24-39.

Peine, K., Heitmann, M., \& Herrmann, A. (2009). Getting a feel for price affect: A conceptual framework and empirical investigation of consumers' emotional responses to price information. Psychology \& Marketing, 26(1), 39-66.

Peter, J. P., \& Olson, J. C. (1987). Consumer behavior and marketing strategy (1st ed.). New York: McGraw-Hill//rwin.

Raghubir, P., Inman, J. J., \& Grande, H. (2004). The three faces of consumer promotions. California Management Review, $46(4), 23-42$.

Rao, A. R., \& Monroe, K. B. (1989). The effect of price, brand name, and store name on buyers' perceptions of product quality: An integrative review. Journal of Marketing Research, 26(3), 351-357. 
Rungtrakulchai, R. (2013). The relationship between price deals, perceived quality, and brand equity for a high involvement product. AU Journal of Management, 11(2), 36-45.

Schindler, R. M. (1998). Consequences of perceiving oneself as responsible for obtaining a discount: Evidence for smartshopper feelings. Journal of Consumer Psychology, 7(4), 371-392.

Shiv, B., \& Fedorikhin, A. (1999). Heart and mind in conflict: The interplay of affect and cognition in consumer decision making. Journal of Consumer Research, 26, 278-292.

Shrout, P. E., \& Bolger, N. (2002). Mediation in experimental and nonexperimental studies: New procedures and recommendations. Psychological Methods, 7(4), 422-445.

Slovic, P., Finucane, M. L., Peters, E., \& MacGregor, D. G. (2007). The affect heuristic. European Journal of Operational Research, 177(3), 1333-1352.

Suri, R., \& Monroe, K. B. (2003). The effect of time constraints on consumers'judgments of prices and products. Journal of Consumer Research, 30(1), 92-104.

Sweeney, J. C., \& Soutar, G. N. (2001). Consumer perceived value: The development of a multiple item scale. Journal of Retailing, 77(2), 203-220.

Sweeney, J. C., Soutar, G. N., \& Johnson, L. W. (1999). The role of perceived risk in the quality-value relationship: A study in a retail environment. Journal of Retailing, 75(1), 77-105.

Teas, R. K., \& Agarwal, S. (2000). The effects of extrinsic product cues on consumers' perceptions of quality, sacrifice, and value. Academy of Marketing Science Journal, 28(2), 278-290.

Urbany, J. E., Bearden, W. O., \& Weilbacker, D. C. (1988). The effect of plausible and exaggerated reference price on consumer perceptions and price search. Journal of Consumer Research, 15(1), 95-110

Yang, Z., \& Peterson, R. T. (2004). Customer perceived value, satisfaction, and loyalty: The role of switching costs. Psychology \& Marketing, 21(10), 799-822

Yin, X., \& Huang, J. (2014). Effects of price discounts and bonus packs on online impulse buying. Social Behavior \& Personality: An International Journal, 42(8), 1293-1302.

Zeithaml, V. A. (1988). Consumer perceptions of price, quality, and value: A means-end model and synthesis of evidence. Journal of Marketing, 52, 2-22.

\section{Submit your manuscript to a SpringerOpen ${ }^{\circ}$ journal and benefit from:}

- Convenient online submission

Rigorous peer review

- Open access: articles freely available online

- High visibility within the field

- Retaining the copyright to your article

Submit your next manuscript at $\gg$ springeropen.com 